Dobson et al. do not consider the likely importance of the road for the land use, mobility, livelihoods and welfare of people living near the park.

Wildlife tourism is a major contributor to Tanzania's economy. But local people, whose land-use practices have created and now maintain the ecosystems valued by Western conservationists, are being dispossessed by state and international elites who capture much of the tourism revenue and reinvest it in conservationincompatible land use.

Wherever the road goes, it will have an environmental impact as well as socio-economic costs and benefits that require rigorous analysis of good data.

Katherine Homewood University College London, UK, k.homewood@ucl.ac.uk Daniel Brockington University of Manchester, UK Sian Sullivan Birkbeck, University of London, UK

\section{International, not 'campus', please}

Your News story on China's science journals (Nature $467,261 ; 2010)$ inaccurately described the Journal of Zhejiang University-Science (JZUS) as a 'campus' journal. In fact, it is an international publication with a pool of some 7,600 referees from more than 67 countries (go.nature. com/pknY2R). On average, $64.4 \%$ of its contributions come from outside Zhejiang University, Hangzhou, of which $50 \%$ are from more than 46 countries and regions. The editorial board is international too.

There are roughly 5,000 science, technology and medical periodicals in China, including more than 200 published in English. Around 1,000 are university ('campus') journals that mostly publish papers from a specific institution, many of which were launched during the country's early reform and opening-up stage from 1978 into the 1980s. This also happened in Japan - the only difference being that most university journals in China are multidisciplinary in content, whereas those in Japan usually focus on one subject or subject group.

Yuehong (Helen) Zhang Journal of Zhejiang University-Science, China,jzus@zju.edu.cn

\section{Reward quality not quantity}

China is not the only country facing a glut of low-impact papers in scientific journals (Nature 467, 252; 2010). Shutting down journals will not help (Nature 467, 261; 2010), as the papers will inevitably resurface elsewhere. As many have pointed out, it is the incentives responsible for the glut that need to change.

What is required is a new academic culture that rewards quality over quantity, an idea whose time has finally come. For example, Germany's main research foundation, the DFG, recently ruled that a maximum of only five papers should be listed in any grant application; compare this with the 10 papers allowed in applications to the US National Science Foundation.

More universities and colleges could limit the number of publications permitted when applying for tenure or promotion. Researchers would then be able to focus their efforts on publishing articles only when there is something substantial to report.

Stan W. Trimble on behalf of 7 co-authors ${ }^{*}$ University of California, Los Angeles, USA, trimble@geog.ucla.edu

${ }^{*}$ A full list of signatories is available online at $h t t p: / / d x$.doi. org/10.1038/467789b

\section{Basic science in Russia under threat}

The president and prime minister of Russia proclaim their support for science and many ambitious projects (Nature 467, 251; 2010). However, the actual support for basic research in Russia will decrease drastically this year.

The main source of peerreviewed funding is the
Russian Foundation for Basic Research (RFBR), a non-profit organization that is largely backed by the state, as well as by voluntary contributions from enterprises, organizations and individuals. Its budget will be cut in 2011 to 6 billion roubles (US\$200 million), half of what it was in 2009.

The budgets managed directly by the Russian ministry of research decreased $4.5 \%$ in 2010 compared with 2009, but are expected to rise in 2011. Although this does not sound that bad, the funds distributed by the ministry seem to be based on nontransparent schemes and arbitrary decisions, and are often awarded without proper peer review.

It is essential to expand state support for the RFBR and save it from closure. The government should recognize that investing in internationally recognized peer-reviewed research is better than funding ambitious and costly projects that have an uncertain outcome.

Yegor Vassetzky Institut Gustave Roussy, France,vassetzky@igr.fr

\section{Better governance to save rainforests}

Urgent measures are needed to help Papua New Guinea to develop sustainably. The country is beset by corporate misdealing and weak governance, and consequently its biologically and culturally rich forests are imperiled.

Attempts by the World Bank and other organizations to improve forest governance have been largely frustrated. As a result, overcutting of forests continues apace, with most accessible forests likely to be logged or to disappear in just one to two decades.

Foreign corporations are driving much of this forest exploitation. Trees are mostly cut by Malaysian logging companies and then shipped as raw logs to Chinese manufacturers of wood products for export.

Papua New Guinea's raw-log exports yield only meagre income and employment for local communities, and proceeds are often concentrated in the hands of political elites.

Environmental prospects in Papua New Guinea might actually be worsening. In May, the country's parliament stripped indigenous groups of important land-protection rights, making it difficult for them to sue offending corporations for environmental damage. The few conservation areas in the country are mostly small and poorly protected, and the government has frozen proposals for 120 new conservation areas to avoid conflicts with loggers. A government pledge to phase out raw-log exports by 2010 has also gone unfulfilled.

Papua New Guinea should immediately reduce its raw-log exports, which will promote local wood-processing industries, training and employment. It should also reinstate the rights of traditional communities to legally challenge foreign corporations for environmental damage. And it should use international climatechange mitigation funds - which could eventually exceed US $\$ 500$ million a year - to promote new conservation areas and improve forest management and governance.

William Laurance on behalf of 6 co-authors ${ }^{*}$ James Cook University, Australia, bill.laurance@jcu.edu.au ${ }^{*} A$ full list of signatories is available online at $h t t p: / / d x . d o i$. org/10.1038/467789d

\section{Left-handed DNA can be right}

I must protest against the knowing groans expended every time a scientist is personally affronted by the image of a lefthanded DNA helix (Nature 467, $401 ; 2010)$. I would remind the groaners that DNA handedness depends on its molecular sequence - witness a seminal paper you published more than 30 years ago: 'Molecular structure of a left-handed double-helical DNA fragment at atomic resolution' (A. H.-J. Wang et al. Nature 282, 680-686; 1979). Albert Erives Dartmouth College, USA, aerives@dartmouth.edu 